\title{
MINERAL TECHNOLOGY
}

$\mathrm{P}^{\mathrm{r}}$ ROSPECTUSES of curricula in the teaching of natural and applied sciences issued periodically by British university and technical training establishments are usually framed on what can reasonably be termed 'catalogue' lines. 'The would-be undergraduate and doubtless his or her parents spend many anxious hours perusing those vital records, to find the answers to precisely what are the subjects to be taught in the career course selected, how the three or four years ahead of them after entry are likely to be spent, and probably of leseer interest at the initial stage, who in the select academy are going to be responsible for their advanced education.

It is particularly refreshing to read and, incidentally, review, a departure from the hide-bound prospectus tradition, in the recent brochure Mineral Technology at the Royal School of Mines, Imperial College of Science and Technology (University of London), South Kensington, London, S.W. $7^{*}$. In this publication we have in the most modern format (reminiscent of some of the artistic and colourful magazines issued as house-organs by our major oil companies and other industrial organizations, deserving a far wider circulation), which completely reverses the purport of a cut-and-dried prospectus.

Mineral technology, as here portrayed, is an invitation. It seeks, most successfully and, let it be said, without ostentation and only a modicum of advertisement (surely blameless all circumstances considered), to tell the doubting aspirant, equally those whose vocational minds are already fixed, what indeed lies ahead of a career in

* Imperial College of Science and Technology (University of London). Minerat Technology at the Royal School of Mines. Pp. 16. (London: Imperial College of Science and Technology, 1063.) applied geology and 'classical mineralogy', an inspired term in the present context.

The message is in this quotation, adequately summarizing the purpose of this issue: "Mineral technology embraces both engineering and scientific aspects of the separation of valuable mineral constituents from their ores. It is concerned with minerals in the sense that chemical engineering is concerned with chemicals and metallurgical engineering with metals, and has much in common with these subjects. Together with the mining geologist and the mining engineer who discover and excavate the ore, the mineral technologist supplies mineral products to the primary consumer either in finished form or as suitable raw material for chemical and metallurgical industry".

Mineral technology as interpreted here covers the essential modern ideas and practices designed to its most comprehensive fulfilment, in outline, as necessarily restricted within its modest sixteen pages and supplement. ary syllabus for the undergraduate course in this subject. The vista embraces liberation and concentration of ores, involving physical methods, physico-chemical methods, chemical methods, auxiliary operations and research. The syllabus for intending students at the Royal School of Mines in this vocation is fully detailed, as also is the advice on opportunities for graduates in this basic mining industry : research, development, production, management and engineering ". . . in all countries conscious of tho need to develop their mineral resources". This publication is a most praiseworthy effort and could with great educational advantage be emulated in other spheres of learning concerned with attracting candidates to work in applied natural sciences.

H. B. Milner

\section{NATURE OF THE LUNAR MARIA}

\author{
By Dr. GILBERT FIELDER \\ University of London Observatory, Mill Hill Park, \\ London, N.W.7
}

T HE question as to the physical and chemical nature of the lunar mare is becoming increasingly important to space scientists. New results reported here are used to discriminate between the various specific origins of maria which have been proposed (Table 1).

Estimates of the age of the maria have been made by several authors ${ }^{1-8}$. Their estimates may be split into three groups (Fig. 1) and these groups give ages which differ grossly. Such large discrepancies are unacceptable for practical purposes.

\begin{tabular}{|c|c|c|}
\hline Author & Origin & Material \\
\hline $\begin{array}{l}\text { Peal (1897) } \\
\text { Warner (1961) } \\
\text { Gold }(1955)\end{array}$ & $\begin{array}{l}\text { Accretion of meteorites and } \\
\text { erosional detritus from slopes } \\
\text { Accretion and erosional detritus } \\
\text { inflling impact craters }\end{array}$ & $\begin{array}{l}\text { Thin dust layer } \\
\text { Thick dust }\end{array}$ \\
\hline $\begin{array}{l}\text { Spurr (1944) } \\
\text { Baldwin (1949) }\end{array}$ & $\begin{array}{l}\text { Igneous sinks } \\
\text { Lava flows initiated by impact } \\
\text { in Mare Imbrium }\end{array}$ & \\
\hline Urey (1952) & $\begin{array}{l}\text { Lavas derived from low-velocity } \\
\text { impacts }\end{array}$ & \\
\hline Kuiper (1954) & $\begin{array}{l}\text { Lava flows initiated by several } \\
\text { individual impacts }\end{array}$ & Lava \\
\hline $\begin{array}{l}\text { von Bulow (1957) } \\
\text { Khabakov (1903) } \\
\text { Fielder (1963) }\end{array}$ & Igneous basins & \\
\hline Wilson (1962) & $\begin{array}{l}\text { Fydrocarbon content of Junar } \\
\text { rocks }\end{array}$ & Asphalt \\
\hline
\end{tabular}

As the maria have a lower crater density than the lunar continents it is elear that the maria post-date the older features of the continents. In principle, crater counts may be used to date the maria relative to the continents. Many of the so-called continental regions are invaded by mare material and, for the count, it is necessary to select a 'pure' continental area.

The area of $2.9 \times 10^{8} \mathrm{~km}^{2}$ defined in Fig. 2 was selected and used to show (Fig. 3) that:

$$
N_{c}=3.2 \times 10^{4} \cdot \Delta^{-2},\left.\right|_{20<\Delta<50 \mathrm{~km}}
$$

where $N_{c}$ is the number of continental craters contained in the diameter range $(\Delta-1 \cdot 25)$ to $(\Delta+1 \cdot 25) \mathrm{km}$.

For craters which are clearly post-mare, it is found (Fig. 3) that, in an area of $6.4 \times 10^{8} \mathrm{~km}^{2}$ covering most of the important maria:

$$
N_{p m}=5 \times 10^{3} \cdot \Delta^{-2}, \mid 10<\Delta<60 \mathrm{~km}
$$

where $N_{p m}$ is the number of post-mare craters in the range $(\Delta-1 \cdot 25)$ to $(\Delta+1 \cdot 25) \mathrm{km}$. Young's data ${ }^{2}$ wore used in the construction of Figs. 3 and 4 and the counts were restricted to those regions within $70^{\circ}$ of the topocentre. 